СОЦАЛЬНА ФІЛОСОФІЯ ТА ФІЛОСОФІЯ ІСТОРІї

\title{
UDK 111:796
}

\section{CONCEPTIAL SPORT FORMATION AS A SOCIA; SYSTEM, SOCIAL INSTITUTE AND SOCIAL MOVEMENT IN CONDITIONS OF GLOBALIZATION}

\author{
CBILOHUR, VLADA \\ Melitopol State Pedagogical University named after Bohdan Khmelnytsky (Melitopol, \\ Ukraine) \\ E-mail: bilovlada@mail.ru, ORCID 0000-0001-9041-7050
}

\begin{abstract}
The relevance of the research consists of the concept of sport is analyzed as an attempt by the state to form an active sports society and the need to develop and implement a self-regulatory mechanism capable of forming sport as a social system, social institute and social movement. Formulation of the task - the concept of sport as a priority direction of social philosophy and philosophy of sport contributes to the formation of sport as a social system, social institution and social movement. The subject of the study is an impact of globalization on the concept of sport as a social system, social institute and social movement. Analysis of recent research and publications. We rely on authors who investigated sport as a phenomenon that acts as a factor in the formation and development of personality. The problem of individual self-determination as a philosophical problem is considered in the philosophical writings of S. Kierkegaard, K. Yaspers, M. Heidegger, J. P. Sartre, A. Kamyu and E.Fromma. The selection of unexplored parts of the general problem is the conceptualization of the concept of sport as a social system, social institution and social movement. Research methodology. The scientific research used the methods of socioacoustic, synergetic, systemic, ontological and comparative analysis, which allowed to form the concept of sport as a priority direction of social philosophy and philosophy of sport and consider sport as an important economic, social and cultural phenomenon, beings. Scientific novelty of the research. This scientific study involves addressing the socio-philosophical meaning of sport, based on the principles of human-dimensionality and humanism. Presenting main material. Interdisciplinary approaches to the problems of contemporary sport as a social system, social institute and social movement are integrated, and the concept of sport is formulated as a priority area of social philosophy and philosophy of sport; the value benchmarks of the concept of sport as a social system, a social institution and a social movement expressing its cultural core are revealed; it is proved that modern sport as a social system, social institute and social movement is an effective means to overcome the crisis phenomena of modern civilization.
\end{abstract}

Conclusion - the impact of globalization on the formation of the concept of sport as a social system, social institute and social movement is shown.

Key words: sports concept, sport as a social system, sport as a social institution, sport as a social movement, globalization, human-dimensionality, humanism

The problem is presented in general terms and its connection with important scientific or practical tasks.

The urgency of the research of the concept of sport as a social system, social institution and social movement, its reflection and practice is due to several reasons: first, the lack of the concept of modern sports as a system for the formation of sports values of young people, who are now gaining significant dynamics of structural changes and creativity in the daily functioning, the development and implementation of which should positively influence the stabilization of society in the conditions of globalization; secondly, the state's efforts to form an active sports society and the need to develop and implement a 
self-regulatory sports mechanism community that flexibly responded to changes in the environment in a globalizing environment; thirdly, a certain deficit of theoretical and methodological reflection of tools and technologies to minimize entropy trends in the crisis society of a globalized society and especially the mechanism of sport as a social institution at the level of an individual and of society as a whole. Today, sport has an impact on virtually all spheres and strata of modern societies and cultures, including education, politics, economics, technology, science, art, mass communication, and leisure. Increasingly, modern sport plays a role in the socialization and upbringing of the younger generation, the formation of an image and lifestyle. It affects such seemingly incompatible phenomena as social status, racial national relations, business life, fashion, and aesthetic values. There are forces in the world that are trying to solve democratic problems through sports, but enough and forces that are trying to solve nationalist or racist tasks. Due to the presence of such forces between them and democratic forces, a political struggle is taking place in the international sports movement [1].

The concept of sport in the languages of globalization has civilized socio-cultural transformations, is included in the general system of international interaction, communicative-information exchange. The concept of sport fits into the system of mass culture of the present and therefore it needs new socio-philosophical substantiations with a humanist orientation to "anthropological excellence" in the conditions of globalization. The urgency of the research topic is that the transformation of social institutions in the conditions of globalization and the formation of new socio-economic relations of modern Ukrainian society requires the formation of the concept of sport as a social system, social institute and social movement. The role of contemporary sports as a system for the formation of value orientations becomes more significant social, political and cultural phenomenon, a factor of viability and state power in modern conditions [2].

\section{Analysis of recent research and publications}

The analysis of literature shows that today the theoretical foundations of the institutional organization and the system of social forms of being and the dynamics of the content characteristics of social institutions and the specifics of their functions are insufficiently developed (E. Durkheim, T.Parsons, T.Veblien, R.Merton, M.Oriu ) The serious attention of researchers was paid to the sociocultural aspects of the formation of social institutions in the context of cultural broadcasting and the management of social institutions in traditional, industrial and postindustrial societies (N. Berdyayev, A. Weber, I. Ilyin, A. Losky, J. Heising). However, the Institute of Contemporary Sports as a system for the formation of value orientations of youth in domestic and foreign literature is considered insufficient, as its individual aspects are scattered in various social sciences and humanities. However, the transformation of sport into a social phenomenon, the growth of its authority and influence in the world, various crisis situations associated with it increasingly require the theoretical self-consciousness of this complex social phenomenon, which requires a socio-philosophical analysis. Philosophical comprehension of sport unfolds at the level of self-reflection, which needs to go beyond the situation that is directly perceived and affects people [3].

There should be given off two groups of scientific publications, which address the socio-philosophical problems of sport in general. The first group of activities' aims at finding new ways, means and methods of humanizing modern sport as a social institution, enhancing its spiritual, moral and aesthetic value, which are being developed in the context of the constructivist "spirituality-sport-culture", aimed at increasing the humanistic cultural value of modern sport. To this direction, we should include such scientists as E. Berry, J. Cherni, R. Garrett, A. Guttmann, S. Guldenpfenning, S.Kravchik, R.Kretchmar, G.Lenk, J.Lipets, G.Lyushe, P.Maktonosh, M.Milik, R.Ostenrhaudt, G.Vandersvaag, P.Vaiss, A.Vol, K.Hainil, A.Hitanen, B.Urbanovsky, 
E.T.Eigler. Created by the Philosophic Society for the Study of Sport (Philosophical Society for the Study of Sport), for many years, publishes an international magazine on the philosophy of sport (Journal of the Philosophy of Sport) [4]. The second group includes the work of the founder of the modern Olympic movement Pierre de Kubarten, who owns the concept of contemporary Olympism (30 works, 50 brochures, 1200 articles), among which the "Olympic memoirs" (1997) should be highlighted. Among the most prominent scientists in this direction are such scholars as: G. Lena, K. Dima, R. Espi, H. Yuberhost, Dzh.Lipitsey, Dzh.Makeluna, H.Kahigala, Z.Kravchik, F. Landry, M. Leiper, H. Mayer, G. Mlodzikovsky, N. Nissiotis, E. Ozer,

\section{T. Odipanski, D.Perri, A.Pure,} V.Rechek, P.Seppenen. In the center of attention of foreign scientists, who analyze the socio-philosophical ideals and values of sport, are its moral values and, above all, the principles of Fair Play (fair play). Among works of this direction should be devoted to the work of G.Lenko and A.Gunter "Principles of Fair Play", P.M. McPhotos "Fair Play: Ethics in Sport and Education," E.Mainberg "Moral in Sport. Fundamentals of New Ethics of Sport ", K.Heinila" Ethics of Sport ". Until now, there is no holistic concept of sport, given its evolution and the current situation in terms of its sociophilosophical understanding of the social significance of modern sport [5]. The problem of individual self-determination as a philosophical problem is considered in the philosophical writings of S. Kierkegaard, K. Yaspers, M. Heidegger, J. P. Sartre, A. Kamyu, E.Fromma.

\section{Unsolved earlier part of the general problem. Setting objectives}

Despite the valuable content of the Institute of Sports as a form of culture, it is not the guarantor of the preservation of its humanistic value. As practice shows, modern sport easily and quickly changes the direction depending on the fluid socioeconomic conditions of the development of modern society. The consequence of the value reorientation of sport during the reform of modern society was its commercialization and professionalization; therefore there was a threat of loss of its identity, national sports traditions. Even sports today become a means of shaping the social inequality and heterogeneity of modern society. Modern sport is no longer a mono phenomenon, which most people represent. The semi-functionality of the Institute of Sports is manifested in its varieties, each of which develops in accordance with the demands of social practice [6].

The purpose of scientific research is the formation of the concept of sport as a priority area of social philosophy and philosophy of sport.

This target is realized by number of tasks:- to integrate interdisciplinary approaches to the problems of contemporary sports as a social institution on the basis of socio-philosophical knowledge and to promote the formation of the concept of sport as a priority area of social philosophy and philosophy of sport;

- to reveal the value benchmarks of the concept of sport as a social institution, expressing its cultural core;

- Argue that modern sport is an effective means to overcome the crisis phenomena of modern civilization.

The object of research - the formation of the concept of sport as a social system, social institution and social movement.

The subject of the study is the impact of globalization on the concept of sport as a social system, social institute and social movement.

\section{Research methodology}

The scientific research used the methods of socio-acoustic, synergetic, systemic and comparative analysis, which allowed to form the concept of sport as a priority area of social philosophy and philosophy of sport.

\section{Scientific novelty of the research}

This scientific study involves addressing the socio-philosophical meaning of modern sports man to provide an analysis of the semantic characteristics (individual and social) of sports being as an expression of individual and social life of man [5]. 


\section{Presenting main material}

Formation of the concept of sport as a social system, social institution and social movement develops in the context of its multidimensional nature. The development of this concept requires attention to the explanation of the theoretical sources of different spheres - social philosophy, theory and history of culture, general, applied and empirical sociology, political science, social and pedagogical psychology, sports and general pedagogy, social management [7]. In doing so, it is necessary to take into account the extent of the development of theoretical and methodological principles that make it possible to understand the mechanisms of formation and the social nature of sport as a social institution and the mechanisms of its influence on such social processes as socialization and the formation of the humanization of modern sports, enhancement of its spiritual, moral and aesthetic value, and as well as the fortification and alliance with the art of youth subcultures [8].

The study and comparison of the fundamentals of sport as a social system, social institute and social movement in the history of philosophical knowledge is based on the integration of interdisciplinary approaches to the problems of contemporary sports as a social institution. As the sociophilosophical analysis of modern sport shows, at the heart of this interaction, the humanistic beginnings of sport, which are realized only when social activity is oriented towards the development of creative potentials of the individual and not narrowly pragmatic interests. Despite the fact that modern sports are subject to the laws of post-industrial civilization (strengthening its professionalization and commercialization), nevertheless, it remains a fact of culture, in the context of which are implemented not only social and communication, but also existential and anthropological dimensions of human existence.

Sports activity, as an individual, personal effort, is aimed at a unique, single act of human exodus beyond its limits and is of a creative nature. We support the positional-interpersonal conception of modern sport as a system for the formation of value orientations of youth, which involves the analysis of ideological and axiological principles, in the context of which the positional type of communication in the information society is closely linked with the strengthening and growth of the social position as such. In this case, the position itself acts as a unity of culture and action, culture of speech and thought of the athlete, which is associated with the formulation of moral, humanistic goals [9].

The way of being sport as a social value can be explained through the mediation of axiology, because of the existence of the values of the humanitarian culture, which manifests itself through functions: humanistic, axiological, evaluativenormative, integrating, communicative, the function of protecting the inner world of personality from external threats; the function of cultivating the culture of movements, the body, the moral health of people, improving the sensory-emotional sphere, aimed at development, ultimately universal sensuality or spirituality. Human development in sport enriches the spiritual life of society in terms of its saturation with the imagery of the original "I" [10].

The social transformations that occur in the era of globalization in the sporting life of mankind are expressed in the form of processes: 1) increasing the frequency of occurrence, renewal and expansion of habitats, existing and emerging sports; 2) multiplication of the number of sports organizations of the world scale affecting the way of life of the population; 3) increased commercialization; 4) the growth of the scientific equipment of sport as a social institution. Therefore, the trends in the development of modern sports should be called the following features and characteristics: 1) democratization and internationalization, expansion of the geography of modern sports; 2) the emergence of new sports; 3) the rapid development of mass and professional sports; 4) intensive development of women's sports; 5) intensive development of children's and youth sports; 6) the steady development of the calendar of sports 
competitions at the national and international levels; 7) the emergence and intensive development of sports science; 8) the creation of a specialized sports infrastructure system [11].

In our opinion, in the future, the social significance of the Institute of Sport will increase, its influence on the educational and educational spheres, human health will increase; increasing importance will be the scientific provision of sports, the development of various areas of sports science, especially biomedical; The 21st century can become the century for further development of women's sports. When forming the concept of modern sport as a system for the formation of value orientations of youth, the first steps are taken to increase the role of sport in strengthening peace and international understanding, in the realization of other humanistic cultural values [12].

In the framework of this concept of sport as a social system, social institute and social movement, humanistic values are becoming increasingly popular: 1) the focus is on the realization of the humanistic potential of sport as high value orientations; 2) the attitude of athletes to refuse from unilateral commercialization and to replace it with humanistic orientation; 3) transformation of the private property institute from direct material production into the sphere of services - management, intermediary, information, communication, advertising, public relations, telecommunication; 4) the formation of a dialogue as a humanistic value of sport, which is a criterion for the humanity of sport, because the sport is so human, so dialogic; 5) the formation of moral values in sport, based on which moral ideals, following the traditions of culture, in which the spiritual value is valued higher than the material, as post-industrial development tends to uncertainty of ideals, to the relativism of moral values; 6) the fight against the victory at any price, dishonest refereeing, and the "competition of pharmacists" in the style of commercial agreements that undermine the foundations of humanistic sport. Formation of the concept of modern sports as a system of value orientations of young people comes from the fact that the system of modern sports today is: 1) a new and specific sphere of economic and business relations; 2) the type of professional work; 3) the most important economic resource, which significantly influences the level and dynamics of the country's economic development; 4) the possibility of forming a positive image of his country [13].

The prospects for the concept of the humanization of sport as a social system, social institute and social movement are connected with the formation of the holism idea (integrity) as the chief idea of the concept of modern sport in the context of the formation of value orientations of youth, namely the idea of integrity, which is based on the idea of honesty and justice. These humane ideas should be guided not only by athletes, but also by judges and supporters who are at the heart of any sport. Humanization of sport presupposes the existence of not only a large but also mass sports capable of attracting millions of people, so value orientations are the pivotal factor of the concept of sport, since they reflect its content and outline the motives, goals and conditions of the activity in which it is carried out [14 ]

Formation of the concept of sport as a social system, social institution and social movement gives meaning and special significance to the goals that set the angle of vision of the activity and self in the process of their implementation. Among athletes, $37 \%$ of people with a high level of selfactualization, which are characterized by high motivation, a person's orientation to achieve maximum sports result, clear criteria for evaluating the results in sports, are revealed. Creative attitude to professional activity, the realization of their abilities ensure the maximum completeness of personal self-realization of the athlete and thereby determine the extent of contribution to the further development of professional culture in the field of sports [15].

Identification of the valuable bases of modern sport as a social institution expressing the genotype of social life and its cultural core indicates that value orientations 
are the most important elements of the internal structure of the individual, which are formed and consolidated by life experience in the course of socialization and adaptation, are perceived as the horizon of boundary meanings and the basic goals of the life of the individual, as well as the means of their implementation. In the dispositional structure of the personality values of the sport orientation form the higher level of the hierarchy of a certain perception of the conditions of life, their evaluation and behavior in the actual (hereand-now), and in the long-term perspective.

Valuable orientations of sport provide the integrity and stability of the individual, determine the structures of consciousness, control and organize the motivational sphere, instrumental orientations on specific objects of sport and activities and ways of communication as a means of achieving goals. Thus, value orientations in sport are, first and foremost, the advantages of sporting meanings as a vital organization and the willingness to behave in accordance with them. Valuable orientations in sport specify the general orientation of interests and advantages, the hierarchy of sports preferences and samples, target and motivational programs, the level of prestige of advantages and readiness due to volitional components to the realization of a sports project of life. Today in the conditions of globalization broad horizons for the practical self-affirmation of a sports man opens up, which actualize the idea of global socialization. The social institute of sport in such conditions revives and becomes socially significant.

The social model of sport allows an individual to evaluate his attitude towards the environment and, through these relationships, assess his place in society. The Institute of Sports as a form of social, nonproductive activity reproduces certain basic mechanisms of human self-consciousness and self-determination, being the sphere of establishing the cultural meaning of personality. Analyzing this problem, we came to the conclusion that physical activity is a basis, and sports activity involves the analysis of sport as a set of certain relationships of people. Taking into account the sports factor as a set of specific social relations that form some specific value orientations, it was possible to analyze their influence on the formation of the individual and to identify important socio-cultural functions [16].

Sport in general would lose its sociocultural meaning, if not considered as a micro-model of society, which forms certain social relations, reproduces them at different levels and defines as a typical behavior. We have proved that sport to a greater extent than other activities is a carrier of specific social relations, since in this system, as well as in society as a whole, it is necessary to distinguish agents of socialization, specific models of behavior and social interactions. In this communication, he socializes and takes roles through the processes of simulation and identification. Sport, by virtue of its specific nature, creates specific conditions for social adaptation and integration of a person, forming a certain type of behavior [17].

Sport as a socio-cultural factor and a social institution reproduces an alternative to modern culture, creates and strengthens the mechanisms of social and cultural life of a person and forms him as a socially competent person. If in a country sports personality is perceived as the pride of a nation, then the image of an athlete becomes an ideal of worship, the formation of the image of sports life in many representatives of youth takes place. Therefore, sports information about "heroes of sport" is very important in the development of modern society. Sport has amazing properties: it can unite people, acquaint them with each other, strengthen the health, character, and even mental ability of a person, develops such qualities as speed, intelligence, reaction, coordination, patience, strength.

We have proved that the formation of the concept of sport as a social system, social institute and social movement is an effective means to overcome the crisis phenomena of modern civilization. The core of the formation of the structure of a sports lifestyle is the figure of the subject-player as the subject of the sports world. It is he who 
creates in himself and around himself a sports space, which is organized in accordance with personal sports needs. Important features of being an athlete is the accumulation and development of his physical (sports) potential and the transition from subjectivity to subjectivity, which should be understood as the systemic quality of the subject, manifested in the form of various subjective qualities in the interaction of the subject different things. Therefore, the term "subjectivity" is the most adequate in determining the substantive attributes of the athlete as an object and subject of the human-dimensional aspect of sports activity [18].

In addition, the expansion of the range and types of youth subcultures, for which subjects are characterized by deviations in socialization, does not contribute to positive stability in the country, and acts as a brake on social development. All these processes illustrate changes in the sport in the life of modern society. Any problem associated with this social group not only reflects the real state of society as a whole, but also affects the prospects for social development in social, economic and political plans, determining the search for ways of selfrealization of the individual. In the conditions of the commercialization of sport as a social institution, there is an urgent need for a certain part of youth in sports selfaffirmation, which leads to an orientation towards "material interests", which determines the issues of self-realization and the peculiarities of their own path. Due to the increasing importance of the Institute of modern sports, the subject of the care of the modern state should be the subject of the subject of the culture of society and its selfaffirmation in social and personal plans.

An essential aspect of humandimensionality of the concept of sport as a social system, social institution and social movement in determining the degree of correlation of extremely expressed natural data and culturally modified bodily properties of a person, the possibilities of operative intelligence, psychological characteristics of the person (first of all, will, stability, endurance) and moral qualities sense of responsibility, vocation, sociability), correlated on the principle of harmony and as such that do not violate the integrity of the individual. It is sport that is one of the best ways of defining the human dimension, which is one of the ranges of anthropological boundaries (the term S. S. Khoruzhii) [19].

At the edge of this range - inadequate and extraterrestrial for both the body and for the spirit of the load, and within the existence of the athlete, there is another way through the mediation of the warnings sent by the body about the approach of a critical situation. At any moment, the athlete can jumble across the limit in both "big" and "massive" sports. In this case, the next step may be the transition to the Other - in the sphere of illness, the crisis of selfconsciousness, mental fractures. It is the presence on the anthropological boundary that determines the place of sport in the ontological space of culture and its high status in the system of cultural values. The humanistic intension of sport is to approach the limit of opportunities without destroying the person as physically, mentally and psychologically.

Thus, the formation of the concept of sport as a social system, social institution and social movement is also an area of synthesis of diverse activities, or more precisely the types of activities, each of which involves another. In fact, competition and competition are two different types of communication in a sporting environment: sociable, affiliate, and competitiveaggressive.

Competitively-aggressive type of sport is cultivated and supported by commercial sports organizations. Therefore, for the adequate development of sports life, it is necessary to promote the development of a competitive type of sport as anticompetitive, aggressive. It is here that the boundary for which the integrity of the individual may possibly be destroyed, the non-human dimension of sport is born, which, in turn, leads to the loss of sport of its socio-cultural nature. Expansion of the sphere of competitive relations leads to the development of sports, so this kind of 
relationship, emerging, institutionalized institutionalized. After all, sport is a sphere of vital activity, which is highly organized (adversarial) [20].

Today, the formation of the concept of sport as a social system, social institution and social movement occupies an important place in the structure of modern society, and therefore requires their unification into a single conceptual paradigm. What today should be called the philosophy of sport is at an initial stage. In the socio-philosophical analysis of being, life and activities of man, individual social groups, social institutions, movements and society as a whole, it is about identifying their boundary principles, that is, their social nature, purpose settings, place and role in the system of universal culture. In this regard, the development of the socio-philosophical concept of sport as a social system, social institution and social movement. acts as the construction of the metaphysics of sport, if we understand metaphysics in the ancient Greek understanding - as the identification of the boundary foundations of life, life and activity. However, the development of the socio-philosophical concept of sports requires an integrated understanding of this complex social phenomenon, the unification into a single whole of the results of his analysis from the standpoint of aesthetics, ethics, sociology, culture science, computer science, the theory of physical education. This determines the significance of the development of the socio-philosophical concept of sport [21].

\section{Conclusion}

As the analysis shows, the formation of the concept of sport as a social system, social institute and social movement acts as a complex phenomenon that has different forms of being and a rather complex structure. Being a definite form of activity, the concept of sport is in various forms: symbolic, sign, verbal, ideal, objective, it includes norms, values, system of social roles and institutions. The concept of sport is multidimensional; it is a complex, heterogeneous and heterogeneous phenomenon, which includes many divisions, types, directions. All this diversity of directions allows an individual to define himself and measure his possibilities, depending on which physical conditions he has achieved, which he possesses with his instincts and abilities, to what extent they are developed, as the person has mastered the skill and technique. Culture itself transforms the natural forces of man, translating them into another way of existence, carrying out human creation and human-dimensionality, thereby ensuring the reproduction of the entire society. The concept of sport takes part in all processes, demonstrating the highest achievements of a person in the development of physical, mental, personal qualities. Detection and demonstration of the limits of the capabilities that human solidarity forms, which is part of the process of human creation.

\section{СПИСОК ВИКОРИСТАНИХ ДЖЕРЕЛ}

1. Ажажа, М. А. Теоретико-медологічні засади концепції людського капіталу// Ефективність сучасного менеджменту організації: зб. наук. праць.Х.: ХІМБ. 2006. C.267-271.

2. Білогур, В. Є. Філософія спорту як новий науковий напрямок і нова навчальна дисципліна Гуманітарний вісник Запорізької державної інженерної академії 2013. Вип.54. С138-154.

3. Білогур, В. Є. Структура світоглядних орієнтацій сучасної студентської молоді / Вища освіта України: Національна академія педагогічних наук України, Інститут вищої освіти. Київ. 2011.- Вип.3. С.74-80.

4. Білогур, В. Є. Формування концепції сучасного спорту як системи ціннісних орієнтацій молоді в умовах глобалізації // Гілея: науковий вісник. 2013. Вип. 75. С.326328. 
5. Визитей, Н. Н. Социальная природа современного спорта / Н.Н. Визитей. Кишинев: Штиинца, 1980. 84 с.

6. Визитей, Н.Н. Физическая культура и спорт как социальное явление. Кишинев: Штиинца, 1986. $160 \mathrm{c.}$

7. Воронкова, В. Г. Концепции взаимосвязи человека, сознания, разума в контексте виртуально-информационного пространства:методологічний контекст // Философия и космология. 2013.

8. Воронкова, В.Г. Гражданское общество как парадигма, концепт и конструкт социально-философского дискурса// Философия и космология. 2015. Vol. 15.P.198 -215.

9. Завальнюк О. В. Феномен спорту: від філософської теорії до сучасних практик.Київ: Вид-во НПУ ім. М.П.Драгоманова, 2017. 384 с.

10. William, J. Morgan. The Philosophy of Sport: A Historical and Conceptual Overview and a Conjecture Regarding Its Future // Jay Coakley and Eric Dunning (eds.) Handbook of Sports Studies. London: Sage, 2003. P. 205-212.

11. Ганс, Ульрих Гумбрехт. Похвала спортивній красі. Пер з анг./ Г.У.Гумбрехт //.Київ: дух і літера,2012.-216c. Edensor, T. National Identity. Popular Culture and Everyday Life. Oxford -New- York, 2002. C. 74.

12. Ібрагімов, М. «Філософія спорту»: чи буде плідною філософія на ниві спорту? // Молода спортивна наука України.- 2011. Т.4. С. 54.

13. Максименюк, М. Ю.\& Нікітенко, В. О. Формування парадигми інформаційнокомунікативного суспільства як різновиду складної соціальної системи і взаємодії// Гуманітарний вісник Запорізької державної інженерної академії. 2016.Вип. 66. С.266278.

14. Mark, Holowchak\& Heather Lynne Reid. Aretism : an ancient sports philosophy for the modern sports world.- Lanham, Md. : Lexington Books, 2011.P. 15-16.

15. Мельник, В.В. Культура буття людини як соціокультурний феномен Гуманітарний вісник Запорізької державної інженерної академії: [зб.наук.пр.] Запоріжжя: Вид-во ЗДІА, 2015. Вип. 60. С.253-268.

16. Nikitenko, Vitalina.Cultural and social competence creation in the process of English language study: information society aspect // Гуманітарний вісник Запорізької державної інженерної академії. 2016. Вип. 67. С.251-257.

17. Олексенко, Р. И. Философия, мировоззрение и мораль современного предпринимателя как составная экономико-социального развития общества // Социосфера: науч.-метод. и теор. журнал. 2013. Вып.1. С.31.

18. Олексенко, Р. І.Формування концепції креативної особистості як фактор креативно-знаннєвої економіки в умовах викликів глобалізації // Гуманітарний вісник Запорізької державної інженерної академії. 2017.Вип. 71. С.118-126.

19. Robert, A. Mechikoff\& Steven, Estes. A history and philosophy of sport and physical education : from ancient civilizations to the modern world.- Boston, Mass. : McGraw-Hill, 2006. P. 12.

20. Scott, R. Kretchmar.Practical philosophy of sport and physical activity. Champaign, IL : Human Kinetics, 2005.P. 91.

21. Хлєбнікова, А. А. Становлення і розвиток інформаційного суспільства в умовах глобалізації: теоретико-методологічний контекст // Гілея: науковий вісник. 2015. Вип. 92. C. $170-174$.

\section{REFERENCE}

1. Azhazha, M. (2006).Theoretical-medological principles of the concept of human capital // Efficiency of modern management of organization: Sb. sciences works. 267 - 271[in Ukrainian]. 
2. Bilohur, V. (2013). The Philosophy of Sport as a New Science Area and New Educational Discipline Humanitarian Bulletin of the Zaporizhzhya State Engineering Academy.

Issue 54. 138 - 154[in Ukrainian].

3. Bilohur, V. (2011). Structure of ideological orientations of modern student youth / Higher education of Ukraine: National Academy of Pedagogical Sciences of Ukraine, Institute of Higher Education. Kiev. Issue 3. 74 - 80[in Ukrainian].

4. Bilohur, V. (2013). Formation of the Concept of Contemporary Sports as a System of Value Orientations of Youth in the Conditions of Globalization // Gilea: Scientific Bulletin. Issue 75. 326 - 328 [in Ukrainian].

5. Vizithey, H. (1980). The social nature of modern sports / H. Vizithey Chisinau: Shtiintsa, 84[in Russian].

6. Vizithey, H. (1986). Physical culture and sport as a social phenomenon / H.H. Visits Chisinau: Shtiintsa. 160 [in Russian].

7. Voronkova, V. (2013). Concepts of the relationship between man, consciousness, reason in the context of the virtual-information space: the methodological context // Philosophy and cosmology [in Russian].

8. Voronkova, V. (2015). Civil Society as a Paradigm, Concept and Construct of SocialPhilosophical Discourse // Philosophy and Cosmology. Vol. 15. 198 - 215 [in Russian].

9. Zavalniuk, O. (2017). The Phenomenon of Sports: From Philosophical Theory to Modern Practices. - Kyiv: View of the National Academy of Sciences of Ukraine. M. Drahomanov. 384 s. [in Ukrainian].

10. William, J. Morgan (2003). The Philosophy of Sport: A Historical and Conceptual Overview and Conjecture Regarding Its Future // Jay Coakley and Eric Dunning (eds.) Handbook of Sports Studies. London: Sage, 2003. 205 - 212[in English].

11. Hans, Ulrich Humbrecht. Praise sporting beauty. Per with ang. / G. Humbrecht // Kyiv: spirit and letter, 2012. P. 216. Edensor, T. National Identity. Popular Culture and Everyday Life. Oxford-New York, 2002. 74 [in English].

12. Ibragimov M. "Philosophy of Sports": Will a fruitful philosophy in the field of sports? / M. Ibragimov // Young sports science of Ukraine . 2011. Eddition 4. 54[in Ukrainian].

13. Maksimenyuk, M.\&Nikitenko, V. Formation of the Information and Communication Society Paradigm as a Kind of Complex Social System and Interaction. Humanitarian Bulletin of the Zaporozhye State Engineering Academy. 2016.- Issue 66. 266 - 278[in Ukrainian].

14. Mark, Holowchak\&Heather, Lynne Reid. Aretism: an ancient sports philosophy for the modern sports world . - Lanham, Md. : Lexington Books, 2011.15 - 16.

15. Melnyk V. The Culture of Human Being as a Socio-Cultural Phenomenon The Humanitarian Bulletin of the Zaporozhye State Engineering Academy: [ed.n.uk.pr.] Zaporizhzhia: A view of the ZGIA, 2015. Issue 60. 253 - 268[in Ukrainian].

16. Nikitenko, V. Cultural and social competence creation in the process of English language study: information society aspect // Humanitarian Bulletin of Zaporozhye State Engineering Academy. 2016 67. 251 - 257[in English].

17. Olexenko R. Philosophy, world outlook and morality of a modern entrepreneur as a composite of socio-economic development of society // Sociosfera: scientific method. and the theorem. magazine. 2013. Issue1. 31[in Russian].

18. Olexenko, R. Formation of the concept of creative personality as a factor of a creative and knowledge economy in the context of the challenges of globalization // Humanitarian Bulletin of Zaporizhzhya State Engineering Academy. 2017. Sssue 71. 18-126 [in Russian].

19. Robert, A. Mechikoff\& Steven, Estes A history and philosophy of sport and physical education: from ancient civilizations to the modern world. - Boston, Mass. : McGraw-Hill, 2006. 12 [in English]. 
20. Scott, R. Kretchmar.Practical philosophy of sport and physical activity. Champaign, IL: Human Kinetics, 2005.91[in English].

21. Khlebnikova, A. Formation and development of the information society in the conditions of globalization: theoretical and methodological context // Gilea: scientific bulletin. 2015. Issue 92. 170 - 174[in Ukrainian].

БИЛОГУР В. Е. - доктор философских наук, профессор, заведующая кафедрой теории и методики физического воспитания и спортивных дисциплин, Мелитопольский государственный педагогический университет имени Богдана Хмельницкого (Мелитополь, Украина)

E-mail: bilovlada@mail.ru,ORCID:0000-0001-9041-7050

\section{ФОРМИРОВАНИЕ КОНЦЕПЦИИ СПОРТА КАК СОЦИАЛЬНОЙ СИСТЕМЫ, СОЦИАЛЬНОГО ИНСТИТУТА И СОЦИАЛЬНОГО ДВИЖЕНИЯ В УСЛОВИЯХ ГЛОБАЛИЗАЦИИ}

Аннотация. Актуальность исследования в том, что проанализирована концепция спорта стремление государства сформировать активное спортивное общество и необходимостью выработки и внедрения в жизнь саморегулятивного механизма, способного сформировать спорт как сочиальную систему, сочиальный институт и соииальное движение.

Постановка задания - концепция спорта как приоритетного направления сочиальной философии и философии спорта способствует формированию спорта как социальной системы, социального института и социального движения.

Предмет исследования - влияние глобализации на формирование концепции спорта как сочиальной системы, сочиального института и соџиального движения.

Анализ последних исследований и публикаций. Мы опираемся на авторов, которые исследовали спорт как феномен, который выступает фактором становления и развития личности. Проблема самоопределения личности как философская проблема рассматривается в философских работах С.Кьеркегора, К.Ясперса, М.Хайдеггера, Ж.-П.Сартра, А.Камю, Э. Фромма.

Выделение неисследованных частей общей проблемы - конщептуализация спорта как социальной системы, соџиального института и социального движения.

Методология исследования. $B$ научном исследовании использованы методы соииоаксиологического, синергетического, системного, онтологического и сравнительного анализа, которые позволили сформировать концепцию спорта как приоритетного направления сочиальной философии и философии спорта и рассмотреть спорт как важный экономический, сочиальный и культурный феномен. Научная новизна исследования. Данное научное исследование предвидит обращение $к$ сочиально-философскому анализу спорта, которое базируется на основаниях человекомерности и гуманизма. Изложение основного материала. Интегрированы междисииплинарные подходы к проблеме современного спорта как сочиальной системы, сочиального института и сочиального движения и сформирована кониепция спорта как приоритетного направления социальной философии и философии спорта; выявлены ценностные базовые ориентиры концепции спорта как социальной системы, социального института и социального движения, которые выражают его культурологическое ядро; доказано, что современный спорт как сочиальная система, социальный институт и сочиальное движение выступает эффективным способом преодоления кризисных явлений современной циивилизации.

Выводы - раскрыто влияние глобализации на формирование на формирование концепции спорта как сочиальной системы, сочиального института и сочиального движения.

Ключевые слова: концепция спорта, спорт как сочиальная система, спорт как социальньй институт, спорт как соииальное движение, глобализация, человекомерность, гуманизм

BILOHUR, VLADA - Doctor of Philosophy, Professor, Head of the Department of Theory and Methodology of Physical Education and Sport Disciplines, Bogdan Khmelnitsky Melitopol State Pedagogical University (Melitopol,Ukraine)

E-mail: bilovlada@mail.ru,ORCID:0000-0001-9041-7050 


\section{ФОРМУВАННЯ КОНЦЕПЦІЇ СПОРТУ ЯК СОЦАЛЬНОӤ СИСТЕМИ, СОЦАЛЬНОГО ІНСТИТУТУ І СОЦІАЛЬНОГО РУХУ В УМОВАХ ГЛОБАЛІЗАЦЇ}

Анотація.Актуальність дослідження в тому, щзо проаналізовано концепцію спорту як намагання держави сформувати активне спортивне суспільство та необхідністю вироблення $i$ впровадження у життя саморегулятивного механізму, здатного формувати спорт як соиіальну систему, соиіальний інститут та соиіальний рух.

Постановка завдання - концепція спорту як пріоритетний напрям соиіальної філософії та філософії спорту сприяе формуванню спорту як соціальної системи, соиіального інституту і соиіального руху.

Предмет дослідження - вилив глобалізації на формування конщепиії спорту як соціальної системи, соціального інституту і соціального руху.

Аналіз останніх досліджень і публікацій. Ми спираємося на авторів, що досліджували спорт як феномен, що виступає чинником становлення і розвитку особистості. Проблема самовизначення особистості як філософська проблема розглядається в філософських доробках С.К'єркегора, К.Ясперса, М.Хайдеггера, Ж.-П Сартра, А.Камю, Е.Фромма.

Виділення недосліджених частин загальної проблеми - концептуалізація концепту спорту як сочіальної системи, соціального інституту і соціального руху.

Методологія дослідження. $B$ науковому дослідженні використано методи соціаксіологічного, синергетичного, системного, онтологічного та порівняльного аналізу, щяо дозволили сформувати конщепцію спорту як пріоритетного напряму соиіальної філософії $i$ філософії спорту та розглянути спорт як важливий економічний, сочіальний $і$ культурний феномен, істоти.

Наукова новизна дослідження. Дане наукове дослідження передбачає звернення до соиіально-філософського смислу спорту, що базується на засадах людиновимірності та гуманізму.

Виклад основного матеріалу. Інтегровано міждисциплінарні підходи до проблем сучасного спорту як сочіальної системи, сочіального інституту та соціального руху та сформовано конщепцію спорту як пріоритетного напряму сочіальної філософії $і$ філософії спорту; виявлено иіннісні базові орієнтири конщепџї спорту як соціальної системи, соціального інституту та сочіального руху, що виражають його культурологічне ядро; доведено, що сучасний спорт як соиіальна система, соціальний інститут та соціальний рух $\epsilon$ ефективним засобом подолання кризових явищ сучасної цивілізації.

Висновки - показано вплив глобалізаџї̈ на формування конџепції спорту як соџіальної системи, соціального інституту і соціального руху.

Ключові слова: концепція спорту, спорт як соиіальна система, спорт як соиіальний інститут, спорт як соиіальний рух, глобалізація, людиновимірність, гуманізм

Стаття рекомендована до публікаиії д.філософ.н., проф. О. П. Пунченко (Одеса,

Надійшла до редколегіі: 12.06 .2018

Прийнята до друку: 17.06.2618 